American Journal of Applied Sciences 6 (3): 456-462, 2009

ISSN 1546-9239

(C) 2009 Science Publications

\title{
Effect of Ambient Gasess on Respiration of Soil Supporting Four Crops in Central Saudi Arabia
}

\author{
${ }^{1}$ Akram Ali, ${ }^{1}$ Ahmad Alfarhan, ${ }^{2}$ Ibrahim Aldjain and ${ }^{1}$ Nagat Bokhari \\ ${ }^{1}$ Department of Botany and Microbiology, College of Science, \\ King Saud University, P.O. Box 2455, Riyadh 11451, KSA \\ ${ }^{2}$ King Khalid Wildlife Research Centre, \\ Thumamah, C/o. National Commission for Wildlife Conservation and Development, \\ P.O. Box 61681, Riyadh 11575, KSA
}

\begin{abstract}
This study was conducted at four localities (Maseef, Naseem, Oleya and Industrial City) in Riyadh city, KSA to determine the effect of increased tropospheric gases on responses of in situ soil respiration (Rs) of wheat (Triticum aestivum L. cv. Giza 68), broad bean (Vicia faba L. cv. Lara), kidney bean (Phaseolus vulgaris L. cv. Giza 3) and pea (Pisum sativum L. cv. Perfection) rhizosphere soil. These plants were grown to a full-season in pots to recieve four air quality localities treatments. Daily mean of $\mathrm{O}_{3}, \mathrm{SO}_{2}, \mathrm{NO}_{2}$ and $\mathrm{CO}_{2}$ concentrations were recorded by portable gas analyzers in the center of studied localities. The Rs values were measured monthly before seed germination, during all growth stages and after harvesting (October, December, February, April and June) at three times during the day (morning, noon and afternoon) for each stage. The maximum values recorded for $\mathrm{O}_{3}$ in mid June, 2007 were 39, 77, 95 and $166 \mathrm{~nL} \mathrm{~L}^{-1}$, in Maseef, Naseem, Olea and Industrial City localities, respectively. Significant decreases in Rs were observed for all polluted localities in compared Maseef site (less polluted). The greatest decreases in Rs were found at Industrial City followed by Naseem and Oleya. More reductions in Rs were observed for the Industrial City treatments during flowering and grainfill stages, while normal respiration at Maseef area was recorded. This study concluded that $\mathrm{O}_{3}$ injury can reduce the $\mathrm{R}_{\mathrm{s}}$ by decreasing the activities and reactions in soil supporting plants.
\end{abstract}

Key words: Climate change, $\mathrm{CO}_{2}, \mathrm{O}_{3}$, respiration, microbes, Riyadh city

\section{INTRODUCTION}

The role of tropospheric gases like ozone in altering plant growth and development has been the subject of thousands of publications over the last several decades ${ }^{[1,9]}$. Still, there is limited understanding regarding the possible effects of ozone on soil processes. In this study, the ozone effects on the flow of carbon from the atmosphere, through the plant to soils, and back to the atmosphere as a framework. A conceptual model based on some signaling is used to illustrate changes in response to ozone, and to discuss possible feedbacks that may occur. Despite past emphasis on above-ground effects, ozone has the potential to alter below-ground processes and hence ecosystem characteristics in ways that are not currently being considered ${ }^{[3]}$.

Since the Industrial Revolution (around 1750), human activities have substantially added to the amount of heat-trapping greenhouse gases in the atmosphere ${ }^{[2,4]}$. The burning of fossil fuels and biomass (living matter such as vegetation) has also resulted in emissions of aerosols that absorb and emit heat, and reflect light ${ }^{[2]}$. The addition of greenhouse gases and aerosols has changed the composition of the atmosphere. The changes in the atmosphere have likely influenced temperature, precipitation, storms and sea level ${ }^{[2]}$. However, these features of the climate also vary naturally, so determining what fraction of climate changes are due to natural variability versus human activities is challenging. The summary of the atmosphere and climate changes observed during the Industrial Era and, where possible, current understanding of why the changes have occurred are atmosphere, temperature, precipitation, storm and sea level changes ${ }^{[2,4]}$.

The use of vegetation to simulate the response of the terrestrial biosphere to climate changes showed an increase in $\mathrm{C}$ storage on the land after a substantial loss during the transient phase ${ }^{[4]}$. Globally increases in $\mathrm{O}_{3}$ concentrations change in the flux of $\mathrm{C}$ to and from soils (respiration) and cycling of $\mathrm{C}$ and $\mathrm{N}$ will occur.

Corresponding Author: Akram Ali, Department of Botany, Faculty of Science, Zagazig University, Zagazig, Egypt Tel: 00966557554020 Fax: 0096614675833 
This has important implications for the functioning of ecosystems because soil $\mathrm{C}$ and nutrient cycles are closely associated. Due to much debate about how the various roles of agro-ecosystems and natural terrestrial ecosystems in global phenomena will be affected by future changes in climate and a changed atmospheric composition $^{[6]}$. Since terrestrial soils contain about $71 \%$ of total terrestrial C stocks ${ }^{[7]}$, any change in the net flux of carbon into or out of soils may have major repercussions on atmospheric $\mathrm{CO}_{2}$ concentrations and the potential for global change. As the most biologically active portion of soil, the rhizosphere (the soil immediately adjacent to plant roots) is likely to be affected most by environmental stresses.

Therefore, it is essential to understand how specific stressors like $\mathrm{O}_{3}$ will affect the rhizosphere, which acts as an interface between primary carbon processes and primary nutrient and water processes. Exposure of plants to $\mathrm{O}_{3}$ produced an decrease of respiration in the rhizosphere soil of Triticum aestivum ${ }^{[8]}$. Also responses were noted in canola (Brassica napus L.), cotton (Gossypium hirsutum L.), maize (Zea mays L.), and soybean [Glycine $\max (\mathrm{L}$.$) Merr.] in soil respiration$ upon exposure to $\mathrm{O}_{3}$ in growth chambers ${ }^{[9,10]}$.

Functional ecosystems are essential for supplying adequate clean air and water, habitat for wildlife, commercial fiber and food products, recreational resources and for preserving biodiversity ${ }^{[1]}$. In addition to the many natural stresses that may affect ecosystem structure and function, introduced pathogens and pests, including exotic plants and animals and pollution may also extract a toll. Ozone is the most important phytotoxic air pollutant in KSA. It is omnipresent in our ecosystems, even at distance from important sources of the precursor pollutants, often in concentrations that affect plant growth, development and productivity.

Ozone affects above-ground parts of plants directly, but often the first manifestations of exposure are measured below-ground where root growth may be inhibited, respiration increased and symbiotic relationships disrupted ${ }^{[12]}$. Given a sufficient exposure, growth of individual plants may be reduced and normal plant-parasite interactions may be modified. In addition, ozone exposure may disrupt normal development of forest stands resulting in shifts in composition, changes in genetic structure and biodiversity and in impaired ecosystem function. The possible interactions of ozone with a changing climate are unknown, but could, depending on species and specific conditions, range from an amelioration of ozone-induced effects on plant growth to an increase in the deleterious effects of ozone ${ }^{[11]}$.

This research was conducted to focus on respiration in rhizosphere soil of four plants grown under air pollution stresses of four different polluted localities.

\section{MATERIALS AND METHODS}

Experiment: The research study was conducted first for two weeks at greenhouse of Botany and Microbiology Department, College of Sciences, King Saud University, KSA. The seeds of studied plants were planted on a loam soil with a $\mathrm{pH}$ of 6.6. The treatments were begun as soon as plants were reached to $15 \mathrm{~cm}$ length (the time of transferring plants to studied localities). Plants were transferred to four localities (Maseef, Naseem, Oleya and Industrial City) in Riyadh city, KSA. Weeds were controlled during the growth of plants using recommended solution or by hands.

Seeds of wheat (Triticum aestivum L. cv. Giza 68), broad bean (Vicia faba L. cv. Lara), kidney bean (Phaseolus vulgaris L. cv. Giza 3) and pea (Pisum sativum L. cv. Perfection) plants were planted in the last week of October 2006 in 4 m length x $1 \mathrm{~m}$ width $\times 1 / 2$ height pots in rows spaced $0.5 \mathrm{~m}$ apart with seeds spaced $10 \mathrm{~cm}$ apart. The pots were covered with plastic membrane during rainfall.

Atmosphere measurements: Meteorological parameters for all studied localities were measured monthly. Atmospheric gases $\mathrm{O}_{3}, \mathrm{SO}_{2}, \mathrm{NO}_{2}$ and $\mathrm{CO}_{2}$ were measured monthly starting from October till June using AEROQUAL series-200 Monitor with multiheads (Air Monitors Limited, UK). Each month we selected the $1^{\text {st }}$ week for complete daily measuring.

In situ respiration rates (Rs): The Rs ( $\mu$ mol $\left.\mathrm{CO}_{2} \mathrm{~m}^{-2} \mathrm{sec}^{-1}\right)$ was measured using a model 6000-09 soil respiration chamber attached to a model 6400 Portable Photosynthesis System (LICOR, Inc., Lincolyn, NE). It was measured five times: before seed germination, during all growth stages and after harvesting (October, December, February, April and June) at three times during the day (morning, noon and afternoon) for each stage. Approximately $1.0 \mathrm{~h}$ prior to measurements, six plastic rings $(10 \mathrm{~cm}$ diameter $\times 5.0 \mathrm{~cm}$ height) were randomly installed per pot into soil in between rows of wheat, broad bean, kidney bean and pea plants. The rings were inserted to a depth about $1.5 \mathrm{~cm}$ each and allowed to outgas prior to $\mathrm{CO}_{2}$ flux measurements. Also, prior to beginning measurements, the internal $\mathrm{CO}_{2}$ concentrations within the respiration chamber and gas analyzer were reduced to about $100 \mu \mathrm{L} \mathrm{CO}_{2} \mathrm{~L}^{-1}$ below the existing ambient $\mathrm{CO}_{2}$ levels to ensure steady-state flux conditions. After observing that soil $\mathrm{CO}_{2}$ flux activities were indeed steady state, readings were taken for $60 \mathrm{sec}$ with mean $\mathrm{CO}_{2}$ flux rates calculated every $15 \mathrm{sec}$. It was determined during initial procedures that longer reading periods presented problems with excess moisture build up in the gas analyzer. Using the $60 \mathrm{sec}$ ring $^{-1}$ protocol, soil $\mathrm{CO}_{2}$ flux 
Am. J. Applied Sci., 6 (3): 456-462, 2009

rates could be completed in all 16 chambers within a period of 8-h duration. In situ $\mathrm{CO}_{2}$ measurements were repeated on a monthly basis beginning in mid-October, 2006 and finshedd in June, 2007. In January, 2007 due to a very cold, soil respiration rates were initiated in the last two days of the month.

Statistical procedure: Data were analyzed using analysis of variance (ANOVA) procedures for random design. The least Significance Difference (LSD) evaluated the mean differences between the four air quality localities treatments. Statistical analysis was performed using SPSS (version 11).

\section{RESULTS AND DISCUSSION}

Air quality: Mean values of meteorological data including temperature, wind velocity, precipitation and radiation from studied localities experimental sites are summarized in Table 1. It showed low values during months of January, June, October, May and June, and October, November and June for air temperature, humidity, wind velocity and rain-fall, respectively. While an increase in June, January, November and January for air temperature, humidity, wind velocity and rain-fall, respectively. Gradual decrease in the air temperature occur, reaching to a minimum of $18^{\circ} \mathrm{C}$ in January followed by gradual increase reaching to a maximum of $42^{\circ} \mathrm{C}$ in June. On the other hand, the gradual decrease in humidity and rain-fall tend to be in summer months, while wind velocity vary throughout the year. Monthly and daily mean values of gases' $\left(\mathrm{O}_{3}\right.$, $\mathrm{SO}_{2}$ and $\mathrm{NO}_{2}$ ) concentration $\left(\mathrm{nL} \mathrm{L} \mathrm{L}^{-1}\right)$ in Riyadh city, KSA during the growth period of studied crops (2006/2007) were listed in Tables 2, 3. The results showed that $\mathrm{O}_{3}$ levels are higher in the urban (Industrial City and Olea) than in the suburban (Naseem) or surrounding rural sites (Maseef), because the presence of high concentrations of $\mathrm{NO}$ in the city centre is a major cause of destroying $\mathrm{O}_{3}{ }^{[12]}$. When the behavior of the localities is compared, it was observed that monthly values captured at Industrial City were significantly high in comparing to other localities (Table 2). The greatest values follow the highest solar radiation, which is the basis of the photochemical reactions, involving the components of vehicle emissions and other sources. This behavior is typical of the urban areas where $\mathrm{O}_{3}$ quickly increases during the day through the photochemical cycle and just as quickly decreases in the reversible reaction $\mathrm{NO}+\mathrm{O}_{3}=\mathrm{NO}_{2}+\mathrm{O}_{2}^{[11]}$. Industrial City showed the highest $\mathrm{O}_{3}$ values at the mid-day. In every examined day, it is recorded higher concentrations than the other localities, showing values ranging from 43-167 $\mathrm{nL} \mathrm{L}^{-1}$. This site observed the greatest hourly average of $185 \mathrm{~nL} \mathrm{~L}^{-1}$, recorded on 8 June 2007. This is largely believed to be from horizontal air transport, high solar radiation (temperature and light), heavy traffic and a subsequent

Table 1: Mean values of meteorological parameters in Riyadh city, KSA $(2006 / 2007)$

\begin{tabular}{llllll}
\hline & $\begin{array}{l}\text { Air } \\
\text { temperature } \\
\left({ }^{\circ} \mathrm{C}\right)\end{array}$ & $\begin{array}{l}\text { Soil } \\
\left({ }^{\circ} \mathrm{C}\right)\end{array}$ & $\begin{array}{l}\text { Wind } \\
\left({ }^{\circ} \mathrm{C}\right)\end{array}$ & $\begin{array}{l}\text { Rain- } \\
\text { Years/Months }\end{array}$ & $\begin{array}{l}\text { velocity } \\
\left(\mathrm{km} \mathrm{h}^{-1}\right)\end{array}$ \\
$\begin{array}{l}\text { fall } \\
(\mathrm{mm})\end{array}$ \\
\hline October 2006 & 39 & 35 & 30 & 6 & 0.00 \\
November 2006 & 30 & 24 & 33 & 9 & 0.00 \\
December 2006 & 22 & 21 & 35 & 8 & 3.12 \\
January 2007 & 18 & 15 & 36 & 7 & 18.8 \\
February 2007 & 20 & 16 & 35 & 8 & 12.6 \\
March 2007 & 32 & 30 & 30 & 7 & 13.6 \\
April 2007 & 36 & 35 & 30 & 8 & 1.78 \\
May 2007 & 41 & 40 & 28 & 6 & 0.55 \\
June 2007 & 42 & 40 & 22 & 6 & 0.00 \\
\hline
\end{tabular}

Table 2: Monthly mean values of gases concentration in Riyadh city, KSA during the growth period of studied crops (2006/2007)

\begin{tabular}{lllll}
$\begin{array}{l}\text { Localities } \\
\text { Years/Months }\end{array}$ & $\begin{array}{l}\mathrm{O}_{3} \text { levels } \\
(\mathrm{nL} \mathrm{L})\end{array}$ & $\begin{array}{l}\mathrm{SO}_{2} \text { levels } \\
(\mathrm{nL} \mathrm{L})\end{array}$ & $\begin{array}{l}\mathrm{NO}_{2} \text { levels } \\
\left(\mathrm{nL} \mathrm{L}^{-1}\right)\end{array}$ & $\begin{array}{l}\mathrm{CO}_{2} \text { levels } \\
\left(\mu \mathrm{L} \mathrm{L}^{-1}\right)\end{array}$ \\
\hline Maseef & & & & \\
October 2006 & 38 & 13 & 12 & 355 \\
November 2006 & 33 & 13 & 12 & 365 \\
December 2006 & 29 & 13 & 12 & 355 \\
January 2007 & 25 & 11 & 11 & 350 \\
February 2007 & 26 & 10 & 11 & 355 \\
March 2007 & 34 & 11 & 12 & 360 \\
April 2007 & 35 & 13 & 11 & 365 \\
May 2007 & 36 & 12 & 13 & 355 \\
June 2007 & 39 & 12 & 12 & 365 \\
Naseem & & & & \\
October 2006 & 64 & 18 & 22 & 350 \\
November 2006 & 64 & 18 & 22 & 360 \\
December 2006 & 46 & 18 & 15 & 350 \\
January 2007 & 33 & 17 & 15 & 350 \\
February 2007 & 33 & 10 & 13 & 350 \\
March 2007 & 46 & 12 & 14 & 360 \\
April 2007 & 58 & 13 & 16 & 355 \\
May 2007 & 62 & 14 & 19 & 365 \\
June 2007 & 77 & 15 & 20 & 365 \\
Olea & & & & \\
October 2006 & 82 & 24 & 26 & 385 \\
November 2006 & 60 & 23 & 25 & 375 \\
December 2006 & 44 & 23 & 22 & 365 \\
January 2007 & 45 & 16 & 15 & 370 \\
February 2007 & 55 & 16 & 17 & 375 \\
March 2007 & 79 & 16 & 18 & 380 \\
April 2007 & 93 & 18 & 19 & 385 \\
May 2007 & 95 & 19 & 23 & 385 \\
June 2007 & 95 & 29 & 27 & 390 \\
Industrial city & & & & \\
October 2006 & 115 & 29 & 26 & 395 \\
November 2006 & 85 & 24 & 23 & 385 \\
December 2006 & 55 & 20 & 22 & 375 \\
January 2007 & 50 & 15 & 21 & 360 \\
February 2007 & 52 & 20 & 24 & 375 \\
March 2007 & 77 & 25 & 25 & 380 \\
April 2007 & 89 & 33 & 35 & 395 \\
May 2007 & 120 & 35 & 33 & 415 \\
June 2007 & 166 & 41 & 32 & 425 \\
\hline & & & & \\
\hline
\end{tabular}


Table 3: Daily mean values of gases concentration in Riyadh city, KSA during the growth period of studied crops (2006/2007)

\begin{tabular}{lllll}
\hline Localities/Days & $\begin{array}{l}\mathrm{O}_{3} \text { levels } \\
\left(\mathrm{nL} \mathrm{L}^{-1}\right)\end{array}$ & $\begin{array}{l}\mathrm{SO}_{2} \text { levels } \\
\left(\mathrm{nL} \mathrm{L}^{-1}\right)\end{array}$ & $\begin{array}{l}\mathrm{NO}_{2} \text { levels } \\
\left(\mathrm{nL} \mathrm{L}^{-1}\right)\end{array}$ & $\begin{array}{l}\mathrm{CO}_{2} \text { levels } \\
\left(\mu \mathrm{L} \mathrm{L}^{-1}\right)\end{array}$ \\
\hline Saturday & 178 & 43 & 40 & 385 \\
Sunday & 135 & 33 & 32 & 395 \\
Monday & 131 & 33 & 33 & 385 \\
Tuesday & 129 & 32 & 31 & 375 \\
Wednesday & 130 & 30 & 33 & 370 \\
Thursday & 86 & 17 & 11 & 375 \\
Friday & 54 & 11 & 10 & 360 \\
\hline
\end{tabular}

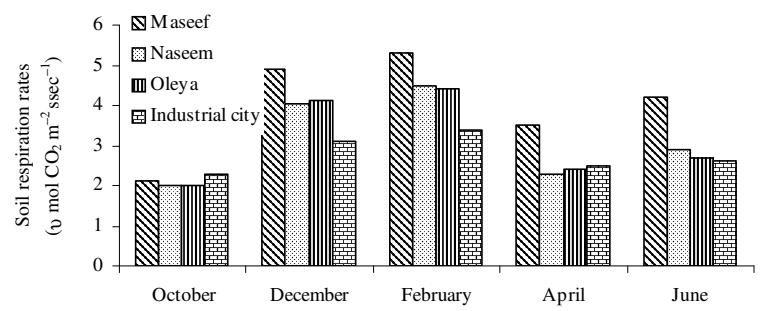

Fig. 1: In situ soil respiration rates $\left(\mu \mathrm{mol} \mathrm{CO}_{2}\right.$ $\mathrm{m}^{-2} \mathrm{sec}^{-1}$ ) for soils of wheat grown in pots under four air quality localities treatments at Riyadh city, KSA

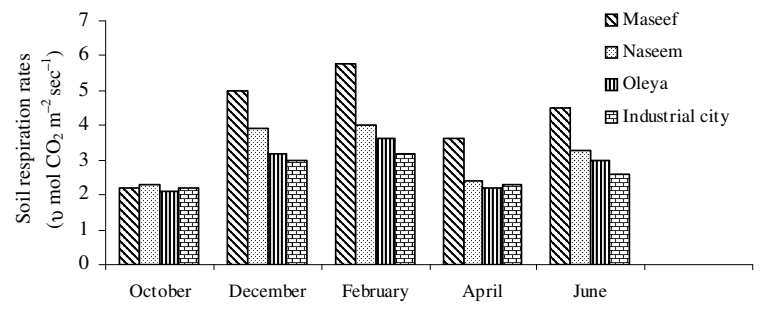

Fig. 2: In situ soil respiration rates $\left(\mu \mathrm{mol} \mathrm{CO}_{2}\right.$ $\mathrm{m}^{-2} \mathrm{sec}^{-1}$ ) for soils of broad bean grown in pots under four air quality localities treatments at Riyadh city, KSA

accumulation of photochemical products, which is common in all big cities ${ }^{[12]}$. This value is above the threshold for public warning (ca. $184 \mathrm{ppb}$ ). Saturday recorded the highest ozone levels in comparing to other days of the week due to the heavy traffic at the beginging of the work days (Table 3 ).

Effect of air quality on Rs rates: The effects of atmospheric $\mathrm{O}_{3}$ on Rs rates for soil supporting wheat at four growth stages of plant development (vegetative, flowering, grainfill and pre-harvesting) are shown in Fig. 1. Pre-seed germination produced non-significant effects for allprepared soils Air quality treatments in four localities caused significant differences during the 1st day of vegetaive growth in compared to pre- cultivation, while significant decreases in the Industrial City site in compared to Maseef site. Moreover, gradual increase in Rs rates during vegetative and flowering stages, then droped starting at grainfill (Fig. 1).

In situ soil respiration rates for soil supporting broad bean plants grown in pots under the effect of four air quality localities are showed in Fig. 2. Naseem, Oleya and Industril City localities exhibited slightly higher rates of respiration, while Maseef area recorde high Rs rates at vegetative growth in compared to soils before seeding. The effect of air quality in Oleya and Industril City localities on $\mathrm{CO}_{2}$ flux rates in soil

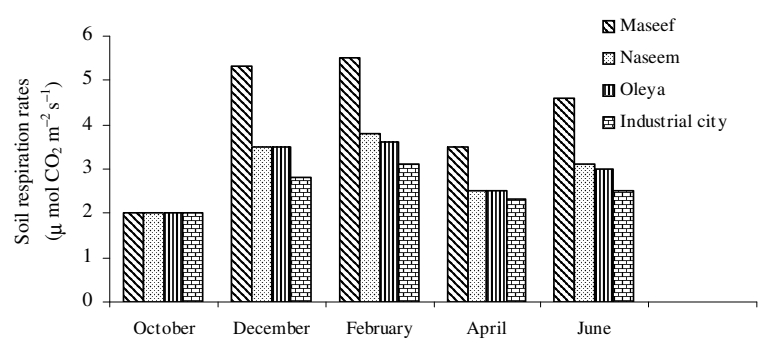

Fig. 3: In situ soil respiration rates $\left(\mu \mathrm{mol} \mathrm{CO}_{2}\right.$ $\mathrm{m}^{-2} \mathrm{sec}^{-1}$ ) for soils of kidney bean grown in pots under four air quality localities treatments at Riyadh city, KSA

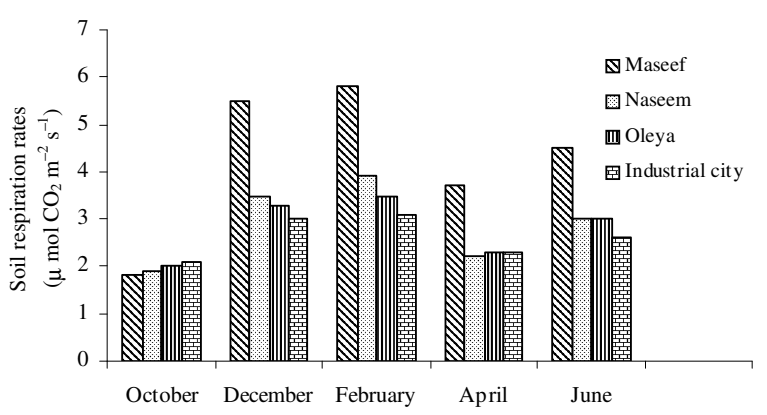

Fig. 4: In situ soil respiration rates $\left(\mu \mathrm{mol} \mathrm{CO}_{2}\right.$ $\mathrm{m}^{-2} \mathrm{sec}^{-1}$ ) for soils of pea grown in pots under four air quality localities treatments at Riyadh city, KSA

supporting broad bean showed little significant decreases in compred to Naseem site. Generally, air quality treatments increased the rates of flux in Maseef in compared to other sites (Fig. 2).

Respiration rates levels in soils of kidney bean plants before seed germination were exactly similar (Fig. 3). In all growth stages, no significant differences between Rs rates of Naseem and Oleya localities. The Rs rates were lowered to low levels at the time of harvesting under air quality treatments of Industril City 
locality. Exposure of kidney bean plants to low $\mathrm{O}_{3}$ significantly deceases the levels of respiration. The highest respiration rates for all growth stages were observed during grainfill development (Fig. 3).

With respect to the combination of elevated $\mathrm{NO}_{2}$, $\mathrm{SO}_{2}$ and $\mathrm{O}_{3}$, respiration levels of pea soils were not only higher before the mid of the day, but also afternoon (Fig. 4). In term of air quality treatment effects, the results were typically significantly different between all studied localities except the times of grainfill and pre-harvesting. During grainfill and preharvesting times, only significant decreases were recorded between all sites and Maseef site (Fig. 4).

Typically, Rs rates found in soils with a recent input of easily degradable substrate. Such substrates would induce a microflora that usually respired more $\mathrm{CO}_{2}$ per unit degradable $\mathrm{C}^{[13]}$. Close relationship were found between the effects of air quality treatments and $\mathrm{CO}_{2}$ fluxes, however, Rs rates as reflecting the activity of whole microbial activity ${ }^{[14]}$. The relationships between Rs rates were found to be linked to climatic conditions. Part of the climatic effect may be explained by an altered quantity of metabolizable substrates due to an influence on primary production or substrate allocation to the roots and decomposition as such in response to climatic conditions ${ }^{[15]}$. The translocation of photosynthetic compounds below-ground made high linking between $\mathrm{CO}_{2}$-fluxes and the stimulation of microbial activity ${ }^{[16]}$.

The flux of $\mathrm{CO}_{2}$ from soil can be a significant component of the carbon budget in an ecosystem. In a prairie environment, soil surface $\mathrm{CO}_{2}$ fluxes were comparable to daily gross photosynthetic rates when averaged over 24 hours $^{[17]}$. Yim et al. ${ }^{[18]}$ found that up to $20 \%$ of net $\mathrm{CO}_{2}$ uptake by a crop could originate in soil. There were strong positive responses to increased soil respiration under atmospheric $\mathrm{CO}_{2}$ concentrations [Fig. 30, 31, 32 and 33 (from 15-17)]. Elevated tropospheric gases decreased the $\mathrm{CO}_{2}$ fluxes for all studied crops. These results agree with that obtained by Stott et al. ${ }^{[19]}$. The respiration of roots, decay of organic matter, and activity of microbes primarily produce soil $\mathrm{CO}_{2}{ }^{[20]}$. Soil respiration is very dependent on soil temperature, organic content, moisture content and precipitation ${ }^{[21]}$. High in situ soil respiration rates due to more $\mathrm{C}$ mineralized as $\mathrm{CO}_{2}$ and transferred to the atmosphere; therefore, such soils acted as net sources of $\mathrm{CO}_{2}{ }^{[22]}$. However, the negative effects resulting from tropospheric $\mathrm{O}_{3}$ treatments on organic $\mathrm{C}$ fractions and respiration appear to have been balanced by the positive effects of higher inputs of decomposable $\mathrm{C}$ belowground. A relatively low Rs in soils under localities treatments is an indication of environmental stress that to repair damages under stress requires soil microbes to divert an increasing amount of energy from growth and reproduction for maintenance and survival ${ }^{[23]}$.

\section{CONCLUSION}

Increases in global climate will not only directly affect the growth of plants, but might also alter the living conditions for soil biota. Part of the climatic effect may be explained by an altered quantity of metabolizable substrates due to an influence on primary production or substrate allocation to the roots and decomposition as such in response to climatic conditions. Significant relationships between $\mathrm{CO}_{2^{-}}$ fluxes and the stimulation of microbial activity may be attributed to the translocation of photosynthetic compounds under ground. The suitable time for detecting $\mathrm{Rs}$ is the period after $12 \mathrm{pm}$ because higher temperatures correlate with soil surface $\mathrm{CO}_{2}$ fluxes and accelerate the development of a soil

\section{ACKNOWLEDGEMENT}

This study is part of the research activities of the Initial Center of Excellence of Biodiversity Research program, developed and funded by the Ministry of Higher Education, KSA. Thanks are expressed to Center of Excellence and anonymous referees for their constructive comments on the first draft of this study.

\section{REFERENCES}

1. Royer, D.L., R.A. Berner and J. Park, 2007. Climate sensitivity constrained by $\mathrm{CO}_{2}$ concentrations over the past 420 million years. Nature,446(7135):530-532.

DOI:10.1038/nature05699

http://www.nature.com/nature/journal/v446/n7135/ abs/nature05699.html

2. Foley, J.A., R. DeFries, G.P. Asner, C. Barford, G. Bonan, S.R. Carpenter, F.S. Chapin, M.T. Coe, G.C. Daily, H.K. Gibbs, J.H. Helkowski, T. Holloway, E.A. Howard, C.J. Kucharik, C. Monfreda, J.A. Patz, I.C. Prentice, N. Ramankutty, P.K. Snyder, 2005. Global consequences of land use. Science, 309(5734): 570- 574.

DOI: $10.1126 /$ science. 1111772

http://www.sciencemag.org/cgi/content/abstract/30 9/5734/570

3. Ali, A.A., 2008. Factors affecting on response of broad bean and corn to air quality and soil $\mathrm{CO}_{2}$ flux rates in Egypt. Accepted in Water, Air and Soil Pollution.

DOI: $10.1007 / \mathrm{s} 11270-008-9748-2$

http://www.springerlink.com/content/100344/?Con tent + Status $=$ Accepted 
4. Hough, A.D. and R.G. Derwent, 1990. Changes in the global concentration of tropospheric ozone due to human activities. Nature, 344: 645-648.

DOI: $10.1038 / 344645 \mathrm{a} 0$

http://www.nature.com/nature/journal/v344/n6267/ abs/344645a0.html

5. Hobbie, S.E., J.P. Schimel, S.E. Trumbore and J.R. Randerson, 2002. Controls over carbon storage and turnover in high-latitude soils. Global Change Biology, 6(S1): 196-210.

DOI: $10.1046 /$ j.1365-2486.2000.06021.x

http://www3.interscience.wiley.com/journal/11905 0284/abstract?CRETRY $=1 \&$ SRETRY $=0$

6. Eggers, J., M. Lindner, S. Zudin, S. Zaehle and J. Liski, 2008. Impact of changing wood demand, climate and land use on European forest resources and carbon stocks during the 21st century. Accepted in Global Change Biology.

DOI: $10.1111 / \mathrm{j} .1365-2486.2008 .01653 . \mathrm{x}$

http://www3.interscience.wiley.com/journal/12011 9100/abstract

7. Lai, R., 2004. Soil Carbon Sequestration Impacts on Global Climate Change and Food Security.

Science, 304(5677): 1632-1627.

DOI: $10.1126 /$ science. 1097396

http://www.sciencemag.org/cgi/content/abstract/30 4/5677/1623

8. McCrady J. K. and C. P. Andersen, 2000. The effect of ozone on below-ground carbon allocation in wheat. Environmental Pollution, 107(3): 465-472. DOI: 10.1016/S0269-7491(99)00122-0 http://www.sciencedirect.com/science?_ob=Article URL\&_udi=B6VB5-3YDGBF0-

R\&_user $=10 \&$ \&doc $=1 \&$ fmt $=$ \&_orig $=$ search \&_so $\mathrm{rt}=\mathrm{d} \&$ view $=\mathrm{c} \&$ _version $=1 \&$ \&urlVersion $=0 \&$ \&useri $\mathrm{d}=10 \& \mathrm{md} 5=514 \mathrm{fc} 6 \mathrm{a} 54 \mathrm{~b} 443 \mathrm{a} 99 \mathrm{c} 92 \mathrm{acf} 4 \mathrm{f} 76952 \mathrm{fb} 8$

9. Andersen, C.P., 2003. Source-sink balance and carbon allocation below ground in plants exposed to ozone. New Phytologist, 157(2): 213-228. DOI:10.1046/j.1469-8137.2003.00674.x http://www3.interscience.wiley.com/journal/11883 3777/abstract

10. Cerdeira, A.L. and S.O. Duke, 2006. The current status and environmental impacts of glyphosateresistant crops. J. Environ. Qual., 35:1633-1658. DOI:10.2134/jeq2005.0378 http://jeq.scijournals.org/cgi/content/abstract/35/5/163

11. Laurence, J.A., 1998. Ecological effects of ozone: integrating exposure and response with ecosystem dynamics and function. Environmental Science \& Policy, 1(3): 179-184.

DOI: 10.1016/S1462-9011(98)00024-0

http://www.sciencedirect.com/science?_ob=Article URL\&_udi=B6VP6-3Y9H12K-

$8 \&$ _user $=10 \&$ \&doc $=1 \&$ fmt $=\&$ \&orig $=$ search $\&$ _so $\mathrm{rt}=\mathrm{d} \&$ view $=\mathrm{c} \&$ _version $=1 \&$ \&urlVersion $=0 \&$ \&useri

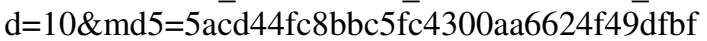

12. Nali, C., C. Pucciariello and G. Lorenzini, 2002. Ozone distribution in central Italy and its effect on crop productivity. Agriculture, Ecosystems \& Environment, 90(3): 277-289.

DOI: $10.1016 / \mathrm{S} 0167-8809(01) 00211-0$

http://www.sciencedirect.com/science?_ob=Article URL\&_udi=B6T3Y-46H6JG8-

$7 \&$ _user $=10 \&$ \&doc $=1 \&$ fmt $=\&$ \&orig $=$ search $\&$ _so $\mathrm{rt}=\mathrm{d} \&$ view $=\mathrm{c} \&$ acct $=\mathrm{C} 000050221 \&$ \& version $=1 \&$ urlVersion $=0 \&$ _userid $=10 \& \mathrm{md} 5=7 \mathrm{fb} 05 \mathrm{bffa} 178 \mathrm{~b} 7 \overline{5}$ $6757544 \mathrm{~b} 75890 \mathrm{f} 141$

13. Anderson, T.H. and K.H. Domsch, 1985. Determination of eco-physiological maintenance carbon requirements of soil microorganisms in a dormant state. Biol. Fertility soil, 1: 81-89.

DOI: $10.1007 / \mathrm{BF} 00255134$

http://www.springerlink.com/content/u1385738147 $47 \mathrm{v} 61 /$

14. Islam, K.R., A.A. Ali and C.L. Mulchi, 2000. Interactions of tropospheric $\mathrm{CO}_{2}$ and $\mathrm{O}_{3}$ enrichments and moisture variations on microbial biomass and respiration in soil. Global Change Biol., 6: 1-11.

DOI: $10.1046 /$ j.1365-2486.2000.00307.x http://www.ingentaconnect.com/bsc/gcb/2000/000 00006/00000003/art00001

15. Walther, G., E. Post, P. Convey, A. Menzel, C. Parmesan, T.J.C. Beebee, J. Fromentin, O. HoeghGuldberg and F. Bairlein, 2002. Ecological responses to recent climate change. Nature, 416: 389-395.

DOI: $10.1038 / 416389 a$

http://www.nature.com/nature/journal/v416/n6879/ full/416389a.html

16. Jensen, L.S., T. Muller, K.R. Tate, D.J. Ross, J. Magid and N.E. Neilsen, 1996. Soil surface $\mathrm{CO}_{2}$ flux as an index of soil respiration in situ: A comparison of two chamber methods. Soil Biol. Biochem., 28(10): 1297-1306.

DOI: $10.1016 / \mathrm{S} 0038-0717(96) 00136-8$

http://www.ingentaconnect.com/content/els/00380 717/1996/00000028/00000010/art00136

17. Raich, J.W. and W.H. Schlesinger, 1992. The global carbon dioxide flux in soil respiration and its relationship to vegetation and climate. Tellus B, 44(2): 81-99.

DOI:10.1034/j.1600-0889.1992.t01-1-00001.x http://www3.interscience.wiley.com/journal/11932 8605/abstract?CRETRY $=1 \&$ SRETRY $=0$

18. Yim, M.H., S.J. Joo and K. Nakane, 2002. Comparison of field methods for measuring soil respiration: a static alkali absorption method and two dynamic closed chamber methods. Forest Ecology and Management, 170(1-3): 189-197. DOI: 10.1016/S0378-1127(01)00773-3

http://www.sciencedirect.com/science?_ob=Article URL\&_udi=B6T6X-44GF148-

$2 \& \_u s e r=10 \& \_r d o c=1 \& \_f m t=\& \_$orig $=$search $\&$ _so $\mathrm{rt}=\mathrm{d} \&$ view $=\mathrm{c} \&$ _version $=1 \&$ \&urlVersion $=0 \&$ \&useri $\mathrm{d}=10 \& \mathrm{md} 5=618365242 \mathrm{a} 145 \mathrm{f} 456 \mathrm{ef} 980208 \mathrm{ec} 61 \mathrm{a} 38$ 
19. Stott, D.E., G. Kassim, W. M. Jarrell, J. P. Martin and K. Haider, 1983. Stabilization and incorporation into biomass of specific plant carbons during biodegradation in soil. Plant and Soil J., 70(1): 15-26.

DOI: $10.1007 / \mathrm{BF} 02374746$

http://www.springerlink.com/content/1437735j6042 $1 \mathrm{~m} 5 \mathrm{n} /$

20. Priora, S.A., H.A. Torberta, G.B. Runiona, H.H. Rogersa and B.A. Kimball, 2008. Free-air $\mathrm{CO}_{2}$ enrichment of Sorghum: Soil carbon and nitrogen dynamics. J. Environ. Qual., 37: 753-758.

DOI: $10.2134 /$ jeq2007.0276

http://jeq.scijournals.org/cgi/content/abstract/37/3/ 753

21. Klamer, M., M.S. Roberts, L.H. Levine, B.G. Drake and J.L. Garland, 2002. Influence of elevated $\mathrm{CO}_{2}$ on the fungal community in a coastal Scrub Oak forest soil investigated with terminalrestriction fragment length polymorphism analysis. Applied and Environmental Microbiology, 68(9): 4370-4376.

DOI:10.1128/AEM.68.9.4370-4376.2002

http://aem.asm.org/cgi/content/full/68/9/4370?ck=n $\underline{\mathrm{ck}}$
22. Norby, R.J., 1987. Nodulation and nitrogenase activity in nitrogen-fixing woody plants stimulated by $\mathrm{CO}_{2}$ enrichment of the atmosphere. Physiologia Plantarum, 71(1): 77-82.

DOI: 10.1111/j.1399-3054.1987.tb04620.x http://www3.interscience.wiley.com/journal/11947 1947/abstract?CRETRY $=1 \&$ SRETRY $=0$

23. Schortemeyer, M., U.A. Hartwig, G.R. Hendrey and M.J. Sadowsky, 1996. Microbial community changes in the rhizospheres of white clover and perennial ryegrass exposed to free air carbon dioxide enrichment (FACE). Soil boil. Biochem., 28: 1717-1724.

DOI: $10.1016 /$ S0038-0717(96)00243-X

http://www.ingentaconnect.com/content/els/00380 717/1996/00000028/00000012/art00243;jsessionid $=9 \mathrm{kej} 41 \mathrm{ca} 61114$. alexandra? format $=$ print 